\title{
Stratejik Siyasal İletişim Bağlamında Referandumlar 16 Nisan 2017 Anayasa Değişikliği Referandumu Twitter Analizi
}

\author{
Emine Kılıçaslana ${ }^{a^{*}}$, Gülsüm Çalışır ${ }^{\mathrm{b}}$ \\ `Aydın Adnan Menderes Üniversitesi, Aydın Meslek Yüksek Okulu, Aydın. \\ ${ }^{b}$ Gümüşhane Üniversitesi, İletişim Fakültesi, Gümüşhane.
}

\section{$\ddot{O} z$}

Türkiye Cumhuriyeti tarihinde yedi defa referanduma gidilmiştir. Birincisi, 1961 ikincisi 1982 Türkiye anayasa referandumu olarak yapılmıştır. Ardından gelen; 1987, 1988, 2007, 2010 ve 2017 referandumlar anayasa değişikliği referandumlar olarak tarihe geçmiş̧ir. Bu referandumlar içinde özellikle 2017 referandumu diğerlerinden farklıdır. Çünkü Cumhurbaşkanı Recep Tayyip Erdoğan, AKP adına 2017 referandumunda Twitter aracilı̆̆ıyla 'EVET' siyasal iletişim kampanyasın yürütmüştür. Bu bağlamda bu çalışmanın amacı demokratik katılımın en önemli göstergelerinden biri olan referandum süreçlerinin siyasal aktörler tarafindan siyasal kampanya platformu olarak kullanılmasının önemini göstermektir. Çalışmanın önemi Cumhurbaşkanı ile diğger siyasal aktörlerin paylaşımlarının farklllıklarına ve benzerliklerine dikkat çekmektir. Bu nedenle sosyal medyanın önemli platformlarnndan olan Twitter'ın Türkiye'de siyasi partiler ve liderleri tarafindan 16 Nisan 2017 anayasa değişikliği referandumunda siyasal kampanyalar açısından kullanım pratiği araştırılacaktır. Araştırmanın kapsamı 1 Mart - 15 Nisan 2017 anayasa değişikliği referandum süreci ile sınırlandırılmıştır. Çalışma, Cumhurbaşkanı ve siyasi parti liderlerinin resmi Twitter hesaplarm referandum sürecine kadar siyasal iletişim bağlamında kendi siyasal kampanyaların nasıl yürüttükleri konusunda nitel söylem analizi çözümlemesi üzerine kurulmuştur. Araştırmanın sonucunda, referandumda 'EVET' cephesinde bulunan AKP ve MHP'nin Twitter' 1 çok yoğun kullandığ tespit edilmiştir. Ayrıca sosyal medya üzerinden pozitif siyasal iletişim kampanya stratejisi yürütmüşlerdir. 'HAYIR' cephesinde yer alan CHP ise referandum süresince sosyal medyayı AKP ve MHP'ye oranla daha az kullanmıştır ve ağırlıkl olarak negatif siyasal iletişim kampanya stratejisini sürdürmüştür. 'EVET've 'HAYIR' cephelerinde yeralan siyasal aktörlerin sosyal medya mecralarından Twitter'ı kullanarak farklı stratejik siyasal iletişim kampanyaları yürüttükleri gösterilmiştir.

Anahtar Kelimeler: Sosyal Medya, Twitter, Referandum, Siyasal İletişim

\section{Referendums in the Context of Strategic Political Communication April 16, 2017 Constitutional Amendment Referendum Twitter Analysis}

\section{Abstract}

There have been seven referendums in the history of the Republic of Turkey. The first was held in 1961 and the second in 1982 as Turkish constitution referendum. Ensuing; The referendums of 1987, 1988, 2007, 2010 and 2017 passed as constitutional amendment referendums. Among these referendum, the 2017 referendum is different from the others. Because President of the republic carried out a quot "YES" political communication campaign through Twitter via the 2017 referendum. In this context, this work demonstrates the importance of using the referendum processes, one of the most important indicators of democratic participation, as a political campaign platform by political actors. The focus of the work is to draw attention to the differences and similarities between the President of the Republic and other political actors. For this reason, Twitter, which is one of the important social media platforms, will be investigated in terms of political campaigns in the constitutional amendment referendum of April 16, 2017 by 
political parties and leaders in Turkey. The scope of the survey was limited to the constitutional amendment referendum process of April 16, 2017 only. The study will be based on the analysis of the qualitative discourse analysis of how the president and political party leaders have conducted their political campaigns in the context of political communication until the referendum process of the official Twitter accounts. As a result, the AKP and the MHP, which are on the 'YES' side of the referendum, have been found to use Twitter extensively. They also carried out a campaign of positive political communication through social media. The CHP, which is on the frontline of 'NO', used social media rarely during the referendum and predominantly negative political communication campaign strategy. It has been shown that political actors in the 'YES' and 'NO' fronts use social media circles to conduct quite different strategic political communication campaigns using Twitter.

Keywords: Social Media, Twitter, Referendum, Political Communication.

\section{GİRIŞ}

Özellikle 2000'li yıllardan sonra bilgi ve iletişim teknolojilerinde yaşanan gelişmeler kamusal yaşamın önemli belirleyicilerinden olmuştur. Bu bağlamda sosyal medya toplumsal ve kültürel değişim ve dönüşümlerin önünü açmıştır.

Sosyal medyanın toplumsal hayatın içine girmesiyle birlikte insanlar özel hayatlarının çoğu ayrıntısını, siyasal ve ideolojik bakış açılarını sosyal medyada paylaşmaya başlamıştır. Bu durum siyasal aktörlerin dikkatini çekmiş, siyasetçiler ve siyaset ile ilgilenen herkesin hızla sosyal medyada yer almasına ve siyasal aktörlerin gerek seçim dönemlerinde gerekse seçim dişı zamanlarda sosyal medya platformlarında siyasal iletişim yapmasına neden olmuştur.

$\mathrm{Bu}$ bağlamda sosyal medyayı siyasal iletişim amaçlı ilk olarak Barack Obama'nın kullandığ1 görülmektedir. Obama'nın 2008, Amerika Birleşik Devletleri Başkanlık seçimlerini kazanmasında sosyal medyanın önemli bir etkisi olduğu ve bu etkinin gelecek seçimler içinde devam edeceği (Smith, 2011: 28) vurgulanmıştır.

Sosyal medyanın kamusal yaşama en önemli etkisi, insanların özel hayatlarını bu platformda paylaşması ile olmaktadır. $\mathrm{Bu}$ anlamda Twitter insanların düşüncelerini, duygularını ve bilgilerini paylaştıkları hayata dair sıradan, siyasal ya da ideolojik yorumlar yaptıkları bir platform olarak ön plana çıkmıştır. Günümüz sıradan insanları için sosyal medya hesabı olmaması ya da bu platformlarda yer almamak bir olumsuzluk olarak algılanmakta ve hemen hemen herkes bu platformlarda yer alarak kendini göstermeye çalışmaktadır.

$\mathrm{Bu}$ gelişmeler siyasal aktörlerin sosyal medyayı kullanmasını bir zorunluluk haline getirmiştir. Özellikle sosyal medyada yer alan kişilerin burada etkin bir şekilde fikirlerini söylemeleri ve tartışmaları bu platformların siyasal tartışmalar açısından önemini daha da artırmaktadır. Bu durum sosyal medya platformlarının insanların siyasi kararlarında etkili olduğunu göstermektedir.

\section{ARAŞTIRMANIN YÖNTEMİ}

Araştırmada söylem analizi yöntemi uygulanmıştır. Bilindiği gibi söylem analizi yöntemi metin yapılarını inceleyen ve aynı zamanda bu metin yapılarındaki; 
anlamlar, fikirler ve ideolojileri de açığa çıkarmak için uygulanan bir analiz türüdür. Bu çalışmada söylem analizini araştırma yöntemi olarak tercih etme nedenimiz söylem analizi yönteminin kısa metinler üzerinde derin inceleme yapılmasını sağlamasından kaynaklanmaktadır. Söylem analizi yöntemi anlamlar arasındaki bağlamı ortaya çıkarmakta ve metinlerin içindeki sözcüklerin anlamlarını göstermektedir.

$\mathrm{Bu}$ nedenle bu çalışmanın amacı demokrasilerin olmazsa olmazı olarak kabul edilen referandum süreçlerinde sosyal medyanın siyasal aktörler tarafından nasıl kullanıldığını incelemektir.

Araştırma analizi söylem analizi üzerine kurulduğu için örnekleme dahil olan siyasi partilerin genel başkanları ve Cumhurbaşkanı' nın tweetleri belirlenen zaman aralığında toplanmıştır. Bu bağlamda özellikle siyasal aktörlerin siyasal ileti seçimleri, sosyal medyada kullandıkları kavramlar ve sözcüklere ayrılarak analiz edilmiştir.

Araştırma Türkiye'de 16 Nisan 2017 refrandum sürecinde siyasi parti genel başkanları ve Cumhurbaşkanı' nın bir siyasal iletişim aracı olarak Twitter'ı kullanım pratiklerinin nitel yöntemlerle incelenmesi üzerine kurulmuştur. Araştırmada; CHP, MHP genel başkanları ile Cumhurbaşkanı' nın resmi Twitter hesaplarında 1 Mart - 15 Nisan 2017 referandum sürecinde paylaştıkları tweetler örneklem olarak seçilmiştir. Bu tweetlerin siyasal anlam taşıyanları söylem analizi yöntemi kullanılarak incelenmiştir.

$\mathrm{Bu}$ bağlamda siyasi parti başkanları ve Cumhurbaşkanı' nın referandum sürecinde en fazla hangi kavram ve sözcükleri kullandıkları ortaya konulmuş ve ayrıca yürüttükleri siyasal iletişim kampanyasının stratejisi ortaya konulmuştur. Kullanılan sözcük ve kavramların siyasal iletişim açısından önemi grafiklerle gösterilmiştir. HDP Genel Başkanı Selahattin Demirtaş tutuklu olduğu için hiçbir paylaşımda bulunmamıştır bu nedenle araştırmada $\mathrm{HDP}^{\prime}$ ye yer verilememiştir.

Çalışmanın kapsamı, 1 Mart - 15 Nisan 2017 sürecinde paylaşılan tweetler ile sınırlandırılmıştır. Bu zaman aralığında, CHP Genel Başkanı Kemal Kılıçdaroğlu, MHP Genel Başkanı Devlet Bahçeli ve AKP' yi temsilen Cumhurbaşkanı Recep Tayyip Erdoğan' nın Twitter paylaşımları örneklem olarak seçilmiştir. Çalışmada sadece referandumla ilgili tweetler ve o tweetlerde kullanılan sözcükler ile kavramların siyasal boyutları incelenmiştir. Ayrıca Cumhurbaşkanı Recep Tayyip Erdoğan, CHP ve MHP parti genel başkanlarının Twitter iletilerinde yeralan birbirini ayırt edici kavramlar ile birbirine benzerlik gösteren kavramlarda ortaya çıkarılmıştır.

$\mathrm{Bu}$ bağlamda söylem analizi çerçevesinde ortaya çıan kavramlar ve sözcüklerin ışığında siyasi parti başkanlarının ve Cumhurbaşkanının referandum sürecinde nasıl bir stratejik siyasal iletişim kampanyası yürüttüğü ortaya çıkmıştır. Ortaya çıkan sonuçlar aşağıda yeralan grafiklerle gösterilmiştir.

\section{SOSYAL MEDYA ve TWITTER}

Bilindiği gibi siyaset toplum üzerinde egemenlik kurma ve iktidar olma olarak tanımlanmaktadır. Kışlalı' ya göre ise siyaset "ülke, devlet, insan yönetimidir." Politika ise "devlete ait işler anlamına gelir (Kışlalı, 1987: 3). Bu bağlamda siyasetçiler ve siyaset ile uğraşan herkesin toplumu etkilemesi en önemli çaba olarak görülmektedir. Bu 
etkilemede siyasal aktörlerin kullandığı çok çeşitli araçlar vardır. Bu araçlara ortaçağdan itibaren bakıldığında ilk olarak gazeteler karşımıza çıkmaktadır. Ardından, radyo, televizyon ve en son sosyal medya bu araçlara eklenerek günümüze değin gelmiştir. Sosyal medyanın eklenmesiyle birlikte siyasal aktörler sosyal medya platformlarında yerlerini hızla almışlardır. Bunun en temel nedeni ise siyasetin yapısından kaynaklanmaktadır. Çünkü siyaset toplumu etkileme ve yönetme çabası olarak tanımlanmaktadır. Bu nedenle bir siyasal aktör için toplum ile sürekli iletişim halinde olmak zorunluluktur. Bu iletişim kurma çabasının arkasında "egemenlik", "iktidar", "yönetme", "manipüle etme" gibi kavramlar olduğu için bu süreç bir çeşit "siyasal iletişim" süreci olarak karşımıza çıkmaktadır. Bu bağlamda, bir siyasal aktör tarafından kullanılan en masum sözcük, sembol ya da kavram siyasal iletişim olgusu içinde değerlendirilmelidir.

Siyasal aktörler tarafından yürütülen siyasal iletişim süreci hedef kitleyi istenilen egemen güç ya da güçler yönünde ikna etmek için çabalamaktadır. Bu ikna etmede kullanılacak olan ideolojik dil jargonu siyaseti yapanlar ve onun çevresi tarafından belirlenmektedir. Hedef kitle ise gönderilen siyasal iletileri içinde yaşadığ kültürel yapı aracılığıyla aldığı için harekete geçmeye hazır bulunmaktadır. Çoğu zaman da hedef kitle, kanaat önderleri aracilığıyla siyasal iletileri kabul etmektedir. Geçmişten bugüne bütün siyasal aktörlerin kendi toplumlarına ulaşmak için kullandıkları çeşitli yöntemler ve araçlar olmuştur. Özelikle Sanayi Devrimi'nden sonra kitle iletişim araçları gelişmeye başlamıştır. Günümüzde ise topluma ulaşmanın en kolay ve rahat yolu radyo ve televizyondan sonra sosyal medya olmaktadır.

Sosyal medyada web siteleri kullanıcılara sadece bilgi ya da herhangi bir hizmet vermemektedir. Sosyal medyayı kullananlara bilgiyi ya da hizmeti verirken aynı zamanda kullanıcılar ile iletişim kurmaktadır yani onları etkilemektedir. Bu etkileşim süreci görüldüğü gibi bu platformu kullanan insanların hızlı bir şekilde değişmesinde de önemli rol oynamaktadır. Sosyal medya ve tanımlarının en tipik buluşma noktası iletişim ortamları olması (Kılıçaslan, 2015: 4) çerçevesinde olmaktadır.

Komito'ya göre, sosyal medya ile ilgili pek çok tanım yapılmaktadır. Medya kuruluşlarının sosyal medya kanallarını kullanımıyla ilgili yapmış olduğu çalışmasında medya kuruluşlarının sosyal medya kanalları ile kurumsal getirilerinin farkına vardıklarını, sosyal ağlar vasıtasıyla okuyucularıyla işletmeler arasındaki etkileşimi sağladığını belirtmiştir (Komito ve Bates, 2009: 232).

Sosyal medya kavramı çevrimiçi ağlar ve paylaşım olgusu üzerinden tanımlanırken terim beş temel özellik üzerinden değerlendirilmektedir (Mayfield, 2008: 5):

- Katılım: Sosyal medya, herkesi katkı sağlama ve geri bildirim konusunda cesaretlendirmektedir. Medya ve izleyici arasındaki çizgiyi bulaniklaştırmaktadır.

- Açıklık: Sosyal medya ağlarının büyük bir bölümü katılım ve geri bildirime açık bir durumdadır. 
- Diyalog: Geleneksel medya içeriğin izleyiciye iletildiği veya dağıtıldığı bir yayıncılık biçimi olarak karşımıza çıkarken, sosyal medya iletişim alıcıyı da sürece dahil ederek iki yönlü bir iletişim biçimi gerçekleştirmektedir.

- Topluluk: Sosyal medya, toplulukların etkili ve hızlı bir biçimde iletişim kurmasına imkan tanırken, ortak ilgi alanlarının paylaşan bireylerin sanal ortamda bir araya gelmelerini sağlamaktadır.

- Bağlantılık: Sosyal medya sitelerinin büyük bir çoğunluğu bağlantılı olma temel özelliği ile başka sitelere, kaynaklara ve insanlara erişim imkanı sunabilmektedir.

Bu bağlamda Twitter'a bakıldığında bir sosyal ağ ve mikroblog sitesi olduğu dikkat çekmektedir. Twitter kullanıcıları 280 karakterlik kısa metinler yazarak duygu, düşünce ve bilgi paylaşımında bulunmaktadır. InSites şirketinin 35 ülkede 9000 kişi üzerinde yaptığı araştırmaya göre dünya üzerinde internet kullanıcılarının \% 80'i Twitter'1 bilmektedir (Netdergim; 2011). Twitter'ın amacı insanların günlük yaşamlarında yaşadıkları, duydukları, düşündükleri ve deneyimledikleri şeylerden paylaşılabilir bulduklarını bir web ortamında başkaları ile kısa ifadelerle paylaşma imkânı sunmaktadır (Altınay, 2014; 36).

Dünyada ve Türkiye'de Twitter kullanımı gün geçtikçe artmaktadır. Bu artış siyasetçilerinde dikkatini çekmiştir. Artık her siyasi aktörün Twitter hesabı bulunmaktadır. Bu siyasi aktörler hem gündem içi hem de gündem dışı tweetler paylaşmaktadırlar.

Tarihsel olarak Twitter'ın artış rakamlarına bakıldığında, Mart 2008'de 1.32 milyon kayıtlı kullanıcısı olan Twitter, bu rakamı Nisan 2009'da 6 milyon, Nisan 2010 'da 105 milyon, Eylül 2010'da 145 milyon ve Eylül 2011'de 200 milyon kayıtlı kullanıcıya çıkarmayı başarmıştır. Dünyada internet kullanıcı sayısı Ocak 2015 itibariyle 3.010 milyar kişi olarak saptanmış bulunmaktadır. Bu sayı, 7.210 milyar olan insan nüfusunun tam yüzde 42'sine tekabül etmektedir. İnternet kullanıcıları arasından tam 2.078 milyar kişi ise aynı zamanda sosyal medyada aktiftir. Bu da toplam insan nüfusu içerisinde yüzde 29' a denk gelmektedir. Dünyada 3.649 milyar kişi mobil telefon/cihaz kullanırken bu kişilerin de 1.685 milyar kişisi sadece mobil cihazlarını sosyal medya hesaplarına girmek kullanmış olarak görünmektedirler (www.medyaakademi.org, 2017).

Türkiye'de Twitter kullanımı, 2009-2010 tarihleri itibariyle yaygınlık kazanmaya başlamıştır. Özellikle genel ve yerel seçimler sürecinde siyasilerin daha aktif oldukları saptanmıştır. Türkiye' de, Twitter kullanıcılarının yüzde 60'ını erkekler, yüzde $40^{\prime}$ ını kadınlar oluşturmaktadır. Kullanıcıların yüzde $64^{\prime}$ ü, 34 yaşın altında ve yüzde 50'sinin eğitim düzeyi üniversite mezunudur. Twitter' in Türkiye'de, kendini geliştirmek isteyen, dünyadaki gelişmeleri olduğu kadar modayı da takip eden ve diğer kültürlerle ilgilenen bir kitlesi bulunmaktadır (webrazzi.com, 2017).

Bu oranlarda kullanıcıların büyük çoğunluğunu yüzde 33 ile 25-34 yaş grubu ve yüzde 28, 16-24 yaş grubu oluşturmaktadır. Bu durum çok yoğun olarak gençlerin 
Twitter'da yer aldıklarının göstergesidir. Ayrıca kullanıcıların yüzde 50'sinin üniversite mezunu olması dikkat çekmektedir.

Günümüzde Twitter'ın kullanıcı sayısının Türkiye'de artış göstermesi siyasal aktörlerin dikkatini çekmiştir. Bu da siyasal aktörlerin Twitter'a daha fazla önem vermesine neden olmaktadır. Twitter ülkemizde siyasi partiler ve liderlerinin en fazla tercih ettikleri sosyal medya platformları arasında bulunmaktadır. Bu nedenle siyasal liderler kendilerine Twitter hesabı açmışlardır. $\mathrm{Bu}$ hesaplardan gerek seçim süreçlerinde gerekse seçim dişı zamanlarda tweet atmaktadırlar. Bu bağlamda özellikle seçim süreçlerinde Twitter paylaşımlarının siyasal iletişim açısından oldukça önemli olduğu görülmektedir.

\section{SIYYASAL İLETIŞi̇ BAĞLAMINDA SOSYAL MEDYA ve REFERANDUMLAR}

Referandum kavramı anlam olarak, geri almak veya getirmek anlamına gelen Latince referre sözcüğünden türemiştir (Online Etymology Dictionary, 2017).

Türk Dil Kurumuna göre referandum "Halkın türlü siyasi ve toplumsal sorunlar karşısında olumlu veya olumsuz görüşünü belirlemek için başvurulan oylamadır" (Türk Dil Kurumu İnternet Sitesi TDK, 2017).

Tarihsel süreçte referandumun ilk uygulamaları özellikle Eski Yunan'da karşımıza çıkmaktadır. Modern anlamda uygulamalar ise Ortaçağ'da İsviçre kantonlarında görülmüştür (www. Britannica.com, 2017).

Referandumların en tipik özelliği devletlerin kamuoyunun herhangi bir konuda (siyasal uygulamalar) görüşünün alınması için oylamaya gitmesi durumudur. Demokrasilerdeki seçimlerden farklı bir uygulama içeriğine sahip olan referandumlar, seçmenlere bir konu hakkında devlet siyasasına ilişkin görüşlerini soran önemli oylamalardır. Özellikle demokratik yönetim biçimlerinde sık sık uygulanmaktadır fakat bazı istisnalar durumunda totaliter yönetim biçimlerinde de görülmektedir.

Bilindiği gibi referandumlar demokrasilerde siyasi krizleri çözmek için kullanılan en önemli siyasal iletişim araçları olarak kabul görmektedir. Bu nedenle referandumlar gerek liberal gerek liberal olmayan demokratik yönetimler için oldukça önem taşımaktadır. Referandum süreçlerinde sosyal medya uygulamalarında:

- Siyasal iletişim kampanya stratejisi,

- Belirlenen kampanya stratejisinin uygulama süreci,

- Uygulama yapılıp seçim süreci bittikten sonra kampanyanın başarısının ölçülmesi açısından oldukça önemlidir.

Türkiye'de dört yılda bir genel seçimler, beş yılda bir yerel seçimler ve yine beş yılda bir Cumhurbaşkanlığı seçimlerinin yapıldığı bir siyasal sistem mevcuttur. Bu yapıya referandumlar da eklendiğinde propaganda açısından kitle iletişim araçlarının ve özellikle sosyal medyanın siyasal kampanya süreçlerinde önemi yadsınamaz. 


\section{16 NISSAN 2017 ANAYASA DEĞİŞIKLİĞİ REFERANDUMU TWITTER ANALIZİ}

16 Nisan 2017 referandumu halk tarafından çok ciddiye alınan ve oldukça yoğun katılımın olduğu önemli bir referandumdur. Referanduma katılan toplam seçmen sayısı, 58.365.078' tir. Toplam seçmen sayısının kullandığ 1 oy, 49.799.163'tür. Referanduma katılım oranı yüzde 85.32 dir. Referandum sonucunda AKP ve MHP'nin destek verdiği 'EVET' yüzde 51.41, CHP ve HDP'nin yer aldığı 'HAYIR' cephesi yüzde 48.59 oranında oy almıştır.

Bu oranları anayasa değişikliği 2010 referandumu ile karşılaştırdığımızda Evet yüzde 57.88, Hayır ise yüzde 42.12 olarak sonuçlanmıştır. Aynı şekilde 2007 anayasa değişikliği referandumuna bakıldığında ise Evet yüzde 68.95, Hayır yüzde 31.05 olarak çıkmıştır.

Bu çalışmada AKP adına Cumhurbaşkanı Recep Tayyip Erdoğan, CHP'yi temsilen Genel Başkan Kemal Kılıçdaroğlu ve MHP'yi temsilen Genel Başkan Devlet Bahçeli'nin referandum süresince attıkları tweetler incelenmiştir. Atılan tweetlerde kullanılan her kavram ve sözcüğün niceliksel olarak kaç kez kullanıldı̆̆ı özel bir bilgisayar programı aracılığıyla tespit edilmiştir. ${ }^{1}$ Ardından bu sözcüklerin referandum ile stratejik siyasal iletişim bağlantısı kurulmuştur. Aynı ideolojik ya da karşıt ideolojik düzlemdeki partilerin kullandıkları kavram ve sözcüklerin benzerlikleri ve farklılıklarına bakılmıştır.

Ayrıca çıkan sonuçlar siyasal aktörlerin hangi siyasal iletişim kampanyası stratejisi yürüttüğünü bize göstermiştir. Bilindiği gibi üç tip siyasal iletişim kampanya stratejisi vardır.

- Pozitif Siyasal İletişim Kampanya Stratejisi: Bu kampanyada siyasal aktör kendini övmekte ve yüceltmektedir. Bu tip kampanyaları genellikle siyasal aktörler 'iktidar' larını korumak için yaparlar. Bu kampanyanın arka planında ben güçlüyüm ve egemen olan benim iletileri bulunmaktadır.

- Negatif Siyasal İletişim Kampanya Stratejisi: Bu kampanyada siyasal aktörler karşı tarafın yaptıklarını kötüleme, kötü gösterme üzerine stratejisini kurmaktadır. Negatif siyasal iletişim kampanyası yapan siyasal aktör karşı tarafı kötüleyerek ben daha iyiyim iletisi göndermektedir. Bu şekilde karşı tarafı zayıflatmaya çalışmaktadır.

- Nötr Siyasal İletişim Kampanya Stratejisi: Bu kampanyada siyasal aktörler ne pozitif ne de negative söylemde bulunmamaktadır. Sadece ortaya konuşarak, belirsiz davranarak kendini göstermeme stratejisi uygulamaktadır. Ayrıca sadece sıradan haberler paylaşarak nötr ileti göndermektedir.

\footnotetext{
${ }^{1}$ Bilgisayar programı sadece bu çalışmada kullanılmak üzere özel olarak yapılmıştır.
} 


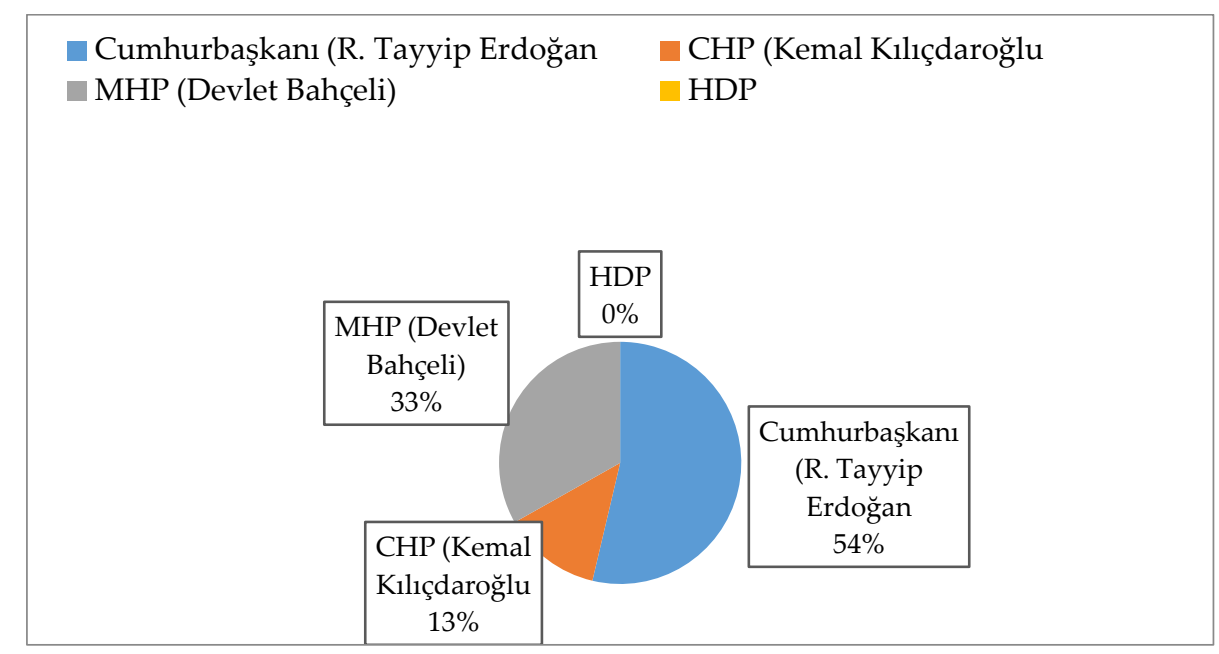

Grafik 1. Cumhurbaşkanı (R. Tayyip Erdoğan), CHP (Kemal Kılıçdaroğlu) ve MHP (Devlet Bahçeli) Tweetlerinin Yüzdelik Grafiği

Cumhurbaşkanı Recep Tayyip Erdoğan'ın Cumhurbaşkanlığ (https://twitter.com/tcbestepe) resmi tweeter sayfasının 4.86 milyon takipcisi vardır. Referandum sürecinde bu sayfadan 102 tweet atılmıştır. Bu 102 tweet grafikte yüzde 54 oranı ile gösterilmiştir. Bu durum Cumhurbaşkanı'nın bu referandum sürecinde en ciddi siyasal kampanyayı yürüttügünü göstermektedir. Cumhurbaşkanı bilindiği gibi AKP adına 'EVET' cephesinin kampanyasının yürütülmesinde oldukça önemli bir görev üstlenmiştir. Bu nedenle Türkiye'nin pek çok yerind siyasal kampanyalar yaparak bu görevi yerine getirmiştir. Referandum kampanya sürecinde ikinci en yüksek tweet oranına Milliyetçi Hareket Partisi Genel Başkanı Devlet Bahçeli'nin sahip olduğunu görmekteyiz. Devlet Bahçeli' nin resmi Twitter sayfasının, 3.6 milyon takipcisi bulunmaktadır. Devlet Bahçeli (https://twitter.com/dbdevletbahceli) 1 Mart 15 Nisan arası 65 tweet atmıştır. Grafikte yüzde 33 olarak yerini almıştır. Her iki partide 'EVET' cephesini temsil etmektedir.

Son olarak 'HAYIR' cephesinden Cumhuriyet Halk Partisi Genel Başkanı Kemal Kılıçdaroğlu' na bakıldığında (https://twitter.com/kilicdarogluk) resmi Twitter sayfasının 4.95 milyon takipçisi vardır. 1 Mart -15 Nisan zaman aralığında sadece 25 tweet atmıştır. En az tweete sahiptir. Grafikte yüzde 13 olarak görülmektedir. 


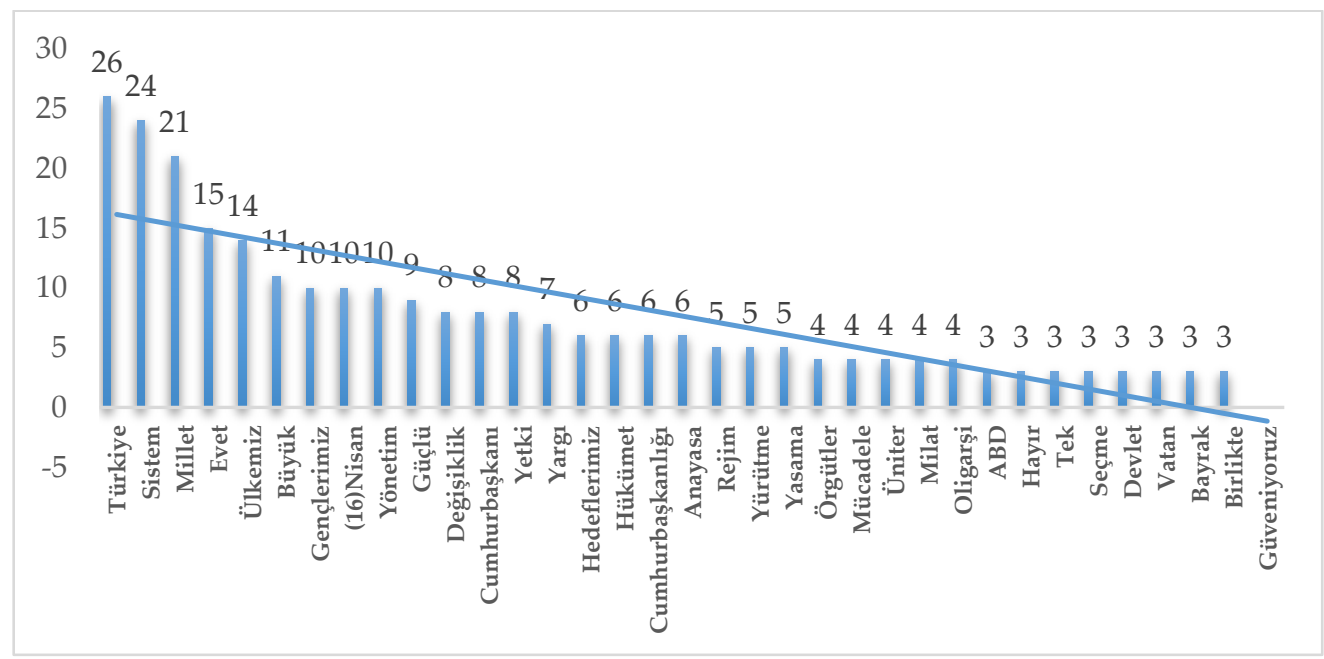

Grafik 2. Cumhurbaşkanı Recep Tayyip Erdoğan ReferandumTweet Örnekleri

Cumhurbaşkanı Recep Tayyip Erdoğan AKP'yi temsilen referandum süresince 102 tweet atmıştır. Cumhurbaşkanı'nın kampanya süresince en fazla "Türkiye, Sistem, Millet, Evet, Ülkemiz, Gençlerimiz, 16 Nisan, Yönetim, Güçlü, Değişiklik, Cumhurbaşkanı, Anayasa, Rejim, Yürütme, Yasama, Örgütler, Mücadele, Üniter, Milat, Oligarşi, ABD, Hayır, Tek, Seçme, Devlet, Vatan, Bayrak, Birlikte, Güveniyoruz" kavram ve sözcükleri kullandığ 1 dikkat çekmektedir.

- Türkiye'nin Üniter Yapısının En Büyük Savunucusu Biz Olduk.(Pozitif)

- Avrupa Birliği'nin 54 senedir bize çektirdiği çile yeter. Türkiye bunların şamar oğlanı değil, herkes haddini bilecek.(Pozitif)

- Bunun için sistemin temel taşlarının yerli yerine oturduğu, sorumlu ve güçlü bir yönetim anlayışını tesis etmeliyiz. (Pozitif)

- İnşallah 16 Nisan'da, gençlerimizin söz sahibi olduğu güçlü bir sistem için, GELECEK İÇİN EVET diyeceğiz.(Pozitif)

- Yeni sistemde hükümeti seçme yetkisi, doğrudan egemenliğin kayıtsız şartsız sahibi olan milletin olacak.(Pozitif)

- Millet için, Bayrak için, Vatan için, Devlet için EVET demeye? (Pozitif)

- TekYürek EVET diyor!(Pozitif)

- Güzel bir Türkiye İçin Tabii ki Evet!(Pozitif)

- Önümüzdeki süreçte de birlik ve dayanışma içinde, aynı kararlılıkla, ülkemize, istiklal ve istikbalimize sahip çıkacağımıza inancım tamdır.(Pozitif)

- Ülkemizi göz göre göre kaosların, siyasi çekişmelerin ve istikrarsızlıkların içine atamayı.(Pozitif)

- Anayasa Değişikliğini Ülkemizin Geleceği İçin İstiyoruz!(Pozitif)

- Davamız büyük, millete olan aşkımız sonsuz.

- Büyük Türkiye'yi, güçlü Türkiye'yi inşa etmek için gençlerimize her zamankinden daha çok ihtiyacımız var.(Pozitif)

- Kendi tecrübesine, birikimine, kabiliyetine güvenen hiç kimse gençlerin seçilme hakkı elde etmesinden rahatsızlık duymaz.(Negatif) 
- Biz gençlerimize güveniyoruz. Gençlere güvenmeyenlerin itimatsızlığı aslında bizatihi kendilerinedir.(Negatif)

- 16 Nisan'da milletimizin takdirine sunulacak olan Anayasa değişikliğiyle demokrasiyi zayıflatmak şöyle dursun, güçlendiriyoruz.

- Bunun için sistemin temel taşlarının yerli yerine oturduğu, sorumlu ve güçlü bir yönetim anlayışını tesis etmeliyiz.

- Evet... Ben 16 Nisan'ın güçlü bir Türkiye için, lider bir Türkiye için, müreffeh bir Türkiye için bir milat olacağına inanıyorum.

- 16 Nisan'da oylayacağımız Anayasa değişikliği, asla bir rejim değişikliği değildir. Bu bir yönetim sistemi değişikliğidir.

- Yeni sistemde Cumhurbaşkanının kanun yapma noktasında yalnızca bütçe kanunu teklif etme yetkisi olacak.

- Yeni sistemde hükümeti seçme yetkisi, doğrudan egemenliğin kayıtsız şartsız sahibi olan milletin olacak.

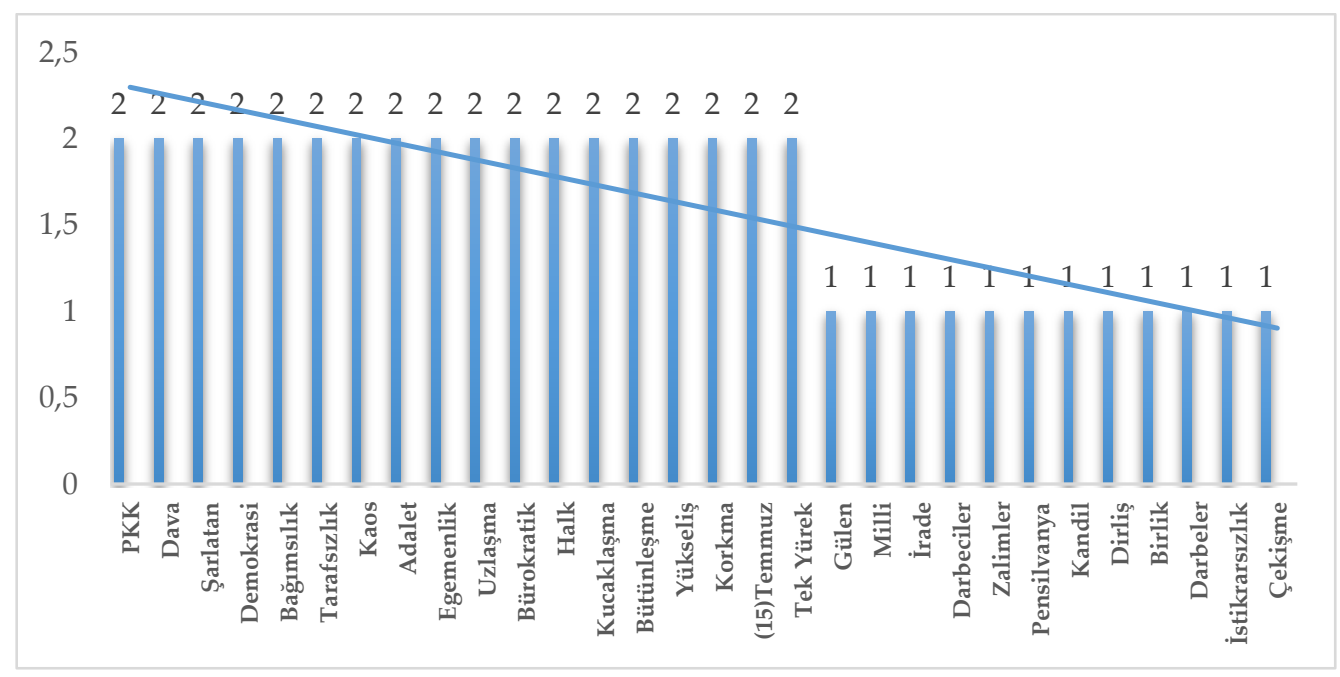

Grafik 3. Cumhurbaşkanı Recep Tayyip Erdoğan ReferandumTweet Örnekleri 2

İkinci grafikte ise Cumhurbaşkanı Recep Tayyip Erdoğan'ın en az kullandığı kavram ve sözcükler yer almıştır. Bunlar; PKK, Dava, Şarlatan, Demokrasi, Bağımsızlık, Tarafsızlık, Kaos, Adalet, Egemenlik, Uzlaşma, Bürokratik, Halk, Kucaklaşma, Bütünleşme, Yükseliş, Korkma, 15 Temmuz, Tek Yürek, Milli, İrade, Darbeciler, Zalimler, Pensilvanya, Kandil, Diriliş, Birlik, Darbeler, İstikrarsızlık, Çekişme" olarak sıralanmıştır.

- Türkiye, yasama, yürütme ve yargı güçleri arasındaki çekişmelerden, yetki karmaşalarından çok büyük zarar gördü.

- Ülkemizi göz göre göre kaosların, siyasi çekişmelerin ve istikrarsızlıkların içine atamayız.

- Darbelerin, muhtıraların yol açtığı siyasi kaoslar ve ekonomik krizler ülkeye ağır bir maliyet yükledi. 
Sonuç olarak bakıldığında gerek en fazla gerekse en az frekansa sahip sözcük ve kavramlar bize AKP'nin bu referandum sürecinde pozitif siyasal iletişim stratejisi izlediğini yukarıda yer alan tweet örneklerinde göstermektedir.

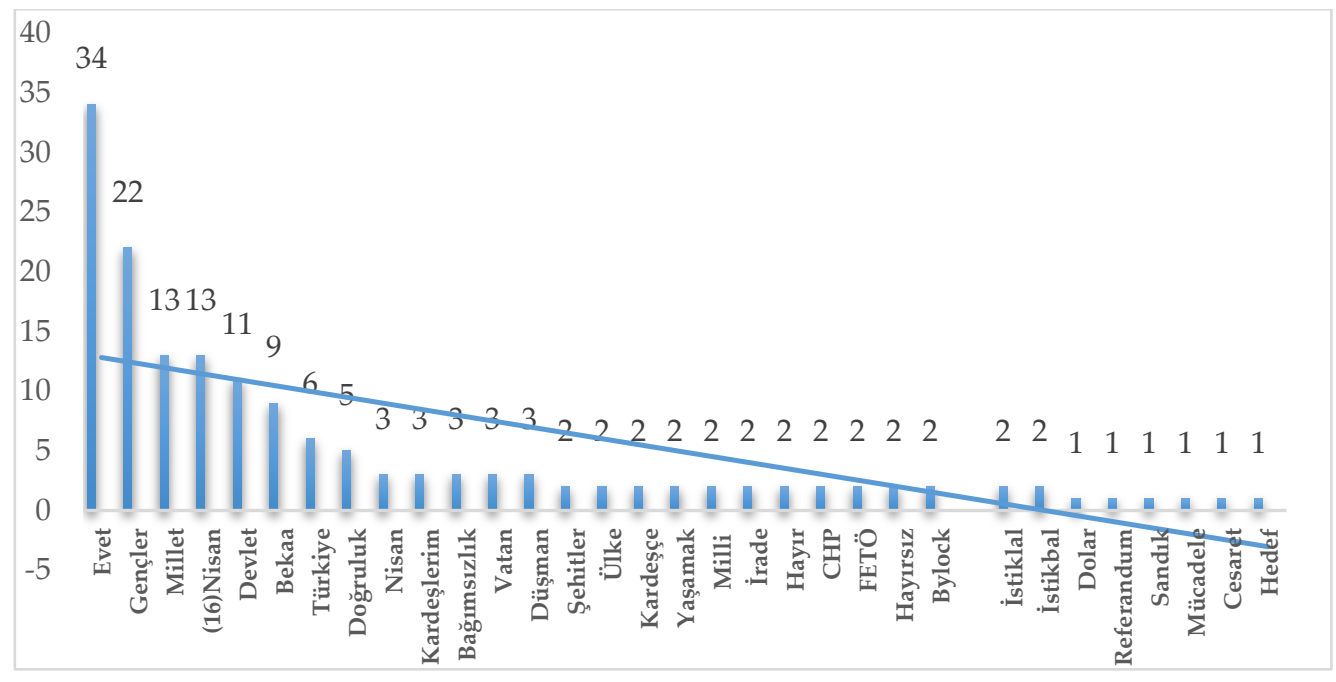

Grafik 4. Devlet Bahçeli Referandum Tweet Örnekleri

Milliyetçi Hareket Partisi Genel Başkanı Devlet Bahçeli referandum sürecinde 65 tweet atmıştır. Bu tweetler bilgisayar programında sayılarak sözcük sözcük ayrılmıştır. Bu sözcüklerden siyasal enformasyon içeren kavram ve sözcükler alınmıştır. Buna göre MHP Genel Başkanı Devlet Bahçeli; "Evet, Millet, Devlet, Türklük, Nisan, Bağımsızlık, Düşman, Ülke, Kardeşçe, Milli, Hayır, FETÖ, Bylock, İstiklal, Dolar, Sandık, Cesaret, Hedef" sözcük ve kavramları üzerine referandum sürecinde kendi stratejik siyasal iletişim kampanyasını yürütmüştür.

- Sıkı tut gençliği, çabuk geçer. Nice sıkı tutsan da gençlik kaçar." Silgiyi kalemden önce bitirmeyin,16 Nisan'da evet deyin.(Pozitif)

- Devletin başına geçen kimse, halkı yönetmeli iyi töreyle." Töreyi hakim ve hadim kılmak için evet diyelim. (Pozitif)

- Genç kardeşim, kınına girmeyen kılıçsın. Kabına sığmayan heyecansın. Özlemlerin var, hayallerin var, hedeflerin var, gerçekleştirmek için evet. (Pozitif)

- Türk gençliği inanıorumki bu ülke için vazgeçilmeyecek yeminlerini tutacak,milleti için evet,devleti için evet,Türkiye için evet diyecektir.(Pozitif)

- Evet, Türk milletinin bağımsızlık meşalesi sonsuza kadar yanacaktır.(Pozitif)

- Milletin Bekası İçin 'Evet' Diyeceğiz.(Pozitif)

- Değerli gençler, bir düşünün Türkiye'yi çünkü düşünmek görmektir, bunu da bilin. Beka en çok sizin için,en çok sizin geleceğinizin güvencesidir.(Pozitif)

- Genç kardeşim, Yunus diyor ki, cümleler doğrudur sen doğru isen, doğruluk bulunmaz sen eğri isen. Sizler doğrusunuz, siz dik duruşsunuz.(Pozitif)

- Fırsatı görmek için uyanıklık, yakalamak için yetenek ve cesaret, ondan istifade için kuvvet ve kararlılık gerekir. Bu Türk gençliğinde vardır. (Pozitif) 
- Diyorlar ki, 18 yaşındaki gencin seçilme hakkına ulaşması anlamsızdır. (Negatif). Sizler Fatih'in İstanbul'u fethettiği yaştasınız, her şey size helaldir.(Pozitif)

- Milliyetçi Hareket Partisi'nin önceliği milletimizin ve devletimizin bekasıdır.(Pozitif)

- Sonuna kadar devlet, sonsuza kadar millet; 16 Nisan'da evet.(Pozitif)

- Biz 16 Nisan'da millet için evet, devlet için evet, Türklüğün bekası için evet diyeceğiz.(Pozitif)

- Egemenliğin yegâne sahibi büyük Türk milleti ülkesinin geleceği hakkında son sözü söylemiş, istiklal ve istikbaline sahip çıkmıştır.(Pozitif)

- 16 Nisan'da, devletin bekası için evet diyeceğiz. (Pozitif)

- Türklüğün bekasını muhafaza için 16 Nisan'da evet kararındayız.(Pozitif).

Yukarıda yeralan Milliyetçi Hareket Parti'sinin attığı tweetlerin söylem analizleri sonuçlarına bakıldığında tamamen slogan ağırlıklı bir pozitif stratejik siyasal iletişim kampanyasının "Milliyet" "Türklük" ve "Devlet" kavramları etrafında özellikle gençlere yönelik olarak yapıldığı görülmektedir.

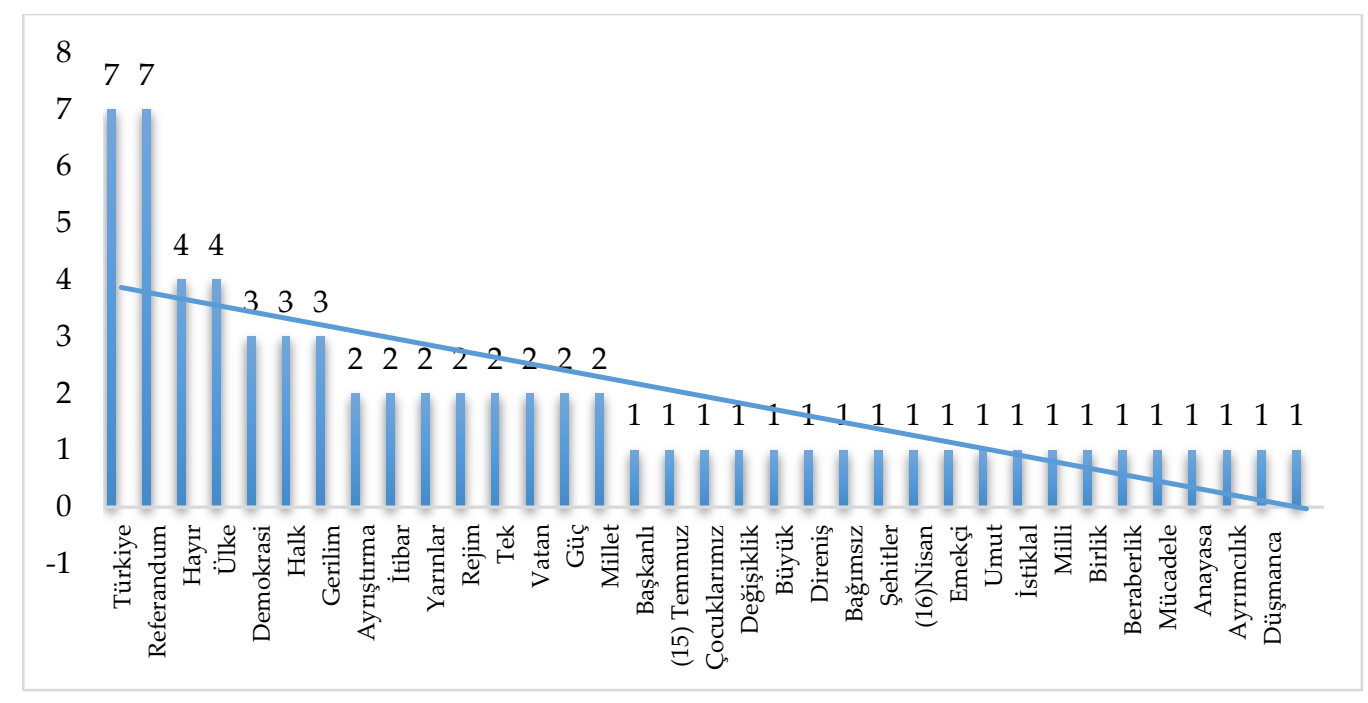

Grafik 5. Kemal Kılıçdaroğlu Referandum Tweet Örnekleri

16 Nisan referandum sürecinde 'HAYIR' cephesinde yer alan Cumhuriyet Halk Partisi Genel Başkanı Kemal Kılıçdaroğlu sadece 25 tweet atmıştır. Bu tweetlere bakıldığında “Türkiye, Referandum, Hayır, Ülke, Demokrasi, Halk, Gerilim, Ayrıştırma, itibar, Yarınlar, rejim, Tek, Vatan, Güç, Başkan, 15 Temmuz, Çocuklarımız, Değişiklik, Büyük, Direniş, Bağımsız, Şehitler, 16 Nisan, Emekçi, Umut, İstiklal, Milli, Birlik, Beraberlik, Mücadele, Anayasa, Ayrımcılık, Düşmanca" sözcük ve kavramları üzerinden stratejik siyasal iletişim kampanyası sürdürmüştür.

- Türkiye' nin gücünü kimse test etmeye kalkmasın" dediler, iktidarları boyunca İsrail, Rusya, Almanya dahil gücümüzü test etmeyen kalmadı! (Negatif)

- Çanakkale'deki büyük direniş, bağımsız Türkiye'nin temelini attı.(Pozitif)

- 15 Temmuz başkanlık sisteminde olsaydı, bugün Türkiye diye bir ülke kalmamıştı. Başkanı ele geçirmek Türkiye'yi ele geçirmek demektir!(Negatif) 
- @BloombergHT ortak yayınında referandum sürecini değerlendireceğim. (Nötr)

- @cnnturk canlı yayınında referandum sürecini ve gündemdeki gelişmeleri değerlendireceğim.(Nötr)

- $\quad$ TRT- TÜRK ve TRT Radyo ortak yayınında gündeme ve referandum sürecine ilişkin açıklamalarda bulunacağım.(Nötr)

- Enerji Bakanı'nın uçağı Irak'a alınmadığında, askerimizin başına çuval geçirildiğinde referandum yok diye mi ses çıkarmaya gerek duymadınız? (Negatif)

- Türkiye'nin ihtiyacı tek adam yönetimi ya da evetçiler-hayırcılar diye ayrışmak değil; tek yürek olup, adaletli bir gelecek inşa etmektir. (Negatif)

- Güneşli yarınlar için, en çok da çocuklarımız için \#HAYIR!(Pozitif)

- Çanakkale, bizi millet iradesine dayalı bir rejime kavuşturan ilk adımdır. 102 yıl sonra rejim değişikliğine HAYIR demek vatan borcumuzdur!(Negatif)

- $\mathrm{Bu}$ millet de, bu ülkenin itibarı da umrunuzda değil. 20 milyon dolara itibarımızı İsrail'e satan hükümet referandum öncesi aslan kesiliyor!(Negatif)

- @cnnturk ve @KanalD ortak yayınında, hafta sonu gerçekleşecek ve ülkemizin kaderini etkileyecek referandumu konuşacağız.(Nötr)

- 15 Temmuz başkanlık sisteminde olsaydı, bugün Türkiye diye bir ülke kalmamıştı.(Negatif)

- Karar hem diplomasiye hem de demokrasinin temel ilkelerine aykırıdır. Düşünce ve ifade özgürlüğü engellenemez.(Negatif)

- Biz Amsterdam'da da, Ankara'da da aynı şeyi istiyoruz: Hiç kimsenin ayrımcılığa uğramadığı tam demokrasi.(Negatif)

- Önümüzdeki süreçte de birlik ve dayanışma içinde, aynı kararlılıkla, ülkemize, istiklal ve istikbalimize sahip çıkacağımıza inancım tamdır.(Pozitif)

Yukarıda yeralan grafik ve tweetlerin sonucuna bakıldığında CHP'nin bu referandum ağırlıklı olarak negatif tweetler kullandığı görülmektedir. Ayrıca pozitif ve nötr mesajlar içeren tweetleri de bulunmaktadır. Bilindiği gibi negatif siyasal iletişim kampanyaları bir başka siyasi partinin ya da var olan durumun olumsuz eleştirilmesi ve kötü gösterilmesi üzerinden yapılmaktadır. Hayır kampanyası yürütmesi ve muhalefet olması da bu negatif stratejik siyasal iletişim kampanyasında belirleyici olmuştur.

CHP'nin genel olarak referandum sürecinde uyguladığ1 pasifist siyasal iletişim politikaları da bir çeşit stratejidir. Bu şekilde AK Partinin kendi varoluşunu gerçekleştirdiği siyasi parti olan $\mathrm{CHP}^{\prime}$ yi grileştirerek AK Partiyi düşmansız bırakma stratejisi uygulanmıştır. 


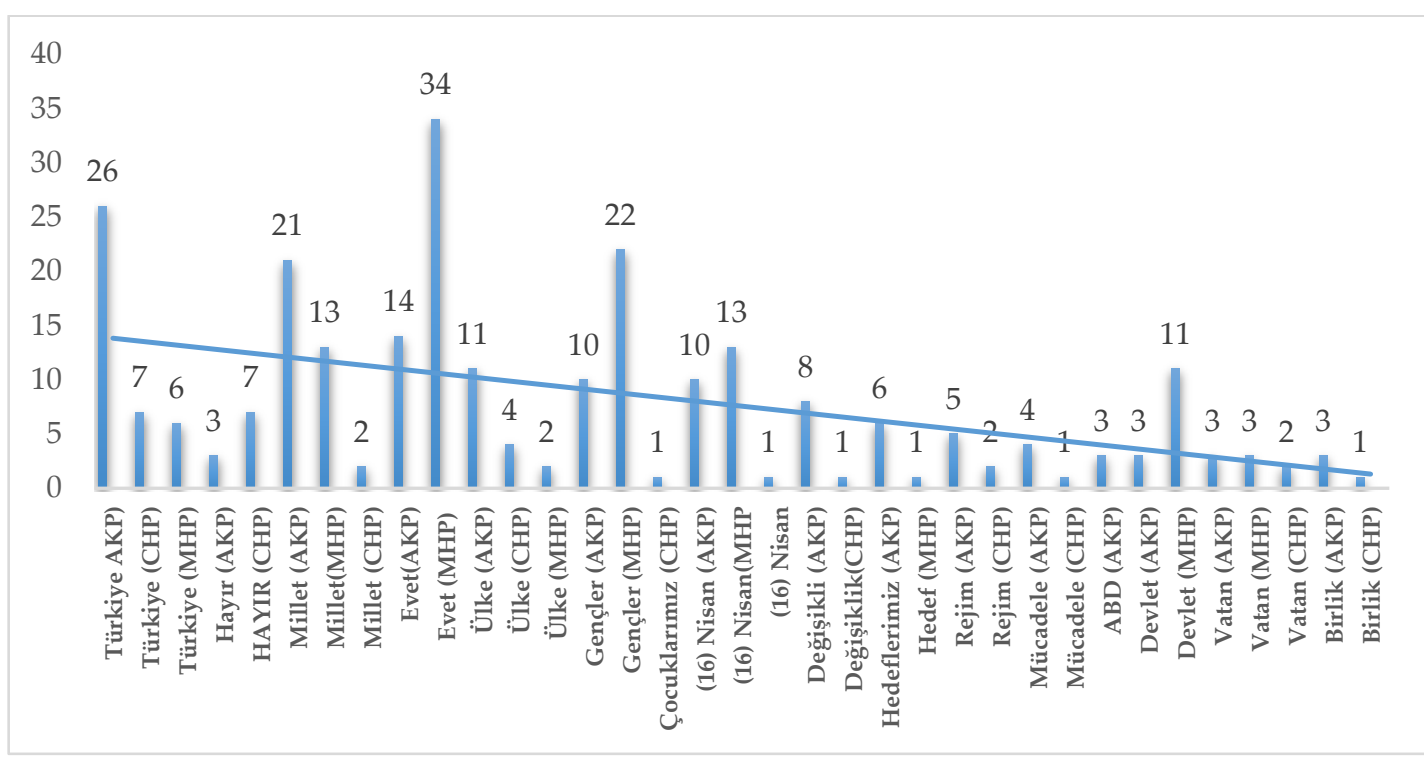

Grafik 6. Cumhurbaşkanı ve Parti Genel Başkanlarının 16 Nisan 2017 Referandum Kampanyasında Kullandığı Ortak Sözcük ve Kavramlar Grafiği

1. Türkiye'nin artık koalisyonlara ve krizlere tahammülü kalmadı. (AKP, Negatif)

1. Türk gençliği inanıyorum ki bu ülke için vazgeçilmeyecek yeminlerini tutacak, milleti için evet, devleti için evet, Türkiye için evet diyecektir. (MHP, Pozitif)

1. Türkiye'nin gücünü kimse test etmeye kalkmasın" dediler, iktidarları boyunca İsrail, Rusya, Almanya dahil gücümüzü test etmeyen kalmadı! (CHP Negatif)

2. Kürt kardeşlerime zulmeden zalimler şimdi 'hayır' diyor (AKP, Negatif).

2. FETÖ'nün fan kulübüne $\mathrm{CHP}^{\prime}$ nin dahil olması hakikaten zillettir, hezimettir. Hayır diyorlar, evet diyenleri de denize dökmekten bahsediyorlar. (MHP, Negatif)

2. Güneşli yarınlar için, en çok da çocuklarımız için \#HAYIR! (CHP, Pozitif)

3. Yarın öyle bir reform yapalım ki, Batı ve teröristler çıldırsın. Milletin evlatları ise bayram yapsin.(AKP, Negatif).

3. Kılıçdaroğlu saçmalıyormuş, yalan yanlış konuşuyormuş, anayasayı açıp okumamış, maddeleri incelememiş, bırakalım milletimiz hükmü versin.(MHP, Negatif)

3. Bu milletde, bu ülkenin itibarı da umrunuzda değil. 20 milyon dolara itibarımızı İsrail'e satan hükümet referandum öncesi aslan kesiliyor! (CHP, Negatif)

4. Egemenliğin yegâne sahibi büyük Türk milleti ülkesinin geleceği hakkında son sözü söylemiş, istiklal ve istikbaline sahip çıkmıştır. (AKP, Pozitif)

4. Türk gençliği inanıyorumki bu ülke için vazgeçilmeyecek yeminlerini tutacak, milleti için evet, devleti için evet, Türkiye için evet diyecektir. (MHP, Pozitif)

4. Bu millet de, bu ülkenin itibarı da umrunuzda değil. 20 milyon dolara itibarımızı İsrail'e satan hükümet referandum öncesi aslan kesiliyor!(CHP, Negatif) 
5. İnşallah 16 Nisan'da, gençlerimizin söz sahibi olduğu güçlü bir sistem için, GELECEK İÇİN EVET diyeceğiz. (AKP, Pozitif)

5. Biz 16 Nisan'da millet için evet, devlet için evet, Türklüğün bekası için evet diyeceğiz. (MHP, Pozitif)

5. Halkın 'HAYIR' iradesini kırmak için Avrupa'da bile gerilim ortamı yaratıyorlar. Halk gerilimden bıktı. 16 Nisan'da bunu onlar da görecek! (CHP, Negatif)

6. Tek Millet, Tek Devlet, Tek Vatan, Tek Bayrak İçin Evet (AKP, Pozitif)

6. Diyorlar ki, 18 yaşındaki gencin seçilme hakkına ulaşması anlamsızdır.Sizler Fatih'in İstanbul'u fethettiği yaştasınız, her şey size helaldir. İş mi, bulunur; aş mı, yapılır; ev mi, alınır; yuva mi, kurulur; para mi, kazanılır; ama vatanın telafisi yoktur, bağımsızlığın ikamesi hiç yoktur. (MHP, Pozitif)

6. Vatan uğruna mücadelemizi, milli birlik ve beraberliğimizi ölümsüzleştiren İstiklal Marşımızın kabulünün 96. yılı kutlu olsun! (CHP, Pozitif).

Yukarıda yeralan grafikte ortak kullanılan en fazla sözcük ve kavramlar yer almıştır. Ortak sözcük ve kavramların pozitif ve negatif olarak dağılımına bakıldığında ise $\mathrm{AKP}^{\prime}$ yi temsilen Cumhurbaşkanının 6 ortak tweetinden 3 tanesinin neagtif diğer geriye kalan 3 tanesinin ise pozitif olduğu görülmektedir. Ortak tweetlerde bir denge stratejisi kurulmuştur.

MHP'yi temsilen Genel Başkan Devlet Bahçeli' nin ortak tweetinden sadece bir tanesi negatif iken geriye kalanlar pozitiftir. MHP'nin ise EVET kampanyasına pozitif siyasal iletişim bağlamında çok büyük destek verdiği görülmektedir.

CHP’yi temsilen Kemal Kılıçdaroğlu'nun 6 tweetinden 4 tanesinin neagtif iken sadece iki tanesinin pozitif olduğu dikkat çekmektedir.

\section{SONUÇ VE TARTIŞMA}

$\mathrm{Bu}$ çalışmada demokratik katılımın en önemli göstergelerinden olan referandum süreçlerinde siyasal aktörler tarafından yürütülen siyasal kampanyaların nasıl yürütüldüğü ve hangi stratejilerin kullanıldığı söylem analizi yöntemi ile incelenerek ortaya konulmuştur. Ayrıca çalışmada Cumhurbaşkanı ile CHP ve MHP parti genel başkanlarının paylaşımlarının farklılıklarına ve benzerliklerine dikkat çekilmiştir. Bu nedenle sosyal medyanın önemli platformlarından olan Twitter' in Türkiye'de Cumhurbaşkanı ve siyasi parti genel başkanları tarafından 16 Nisan 2017 anayasa değişikliği referandumunda siyasal kampanyalar açısından kullanım pratiği gösterilmiştir. Ortaya çıkan sonuçlar yukarıda yer alan grafiklerle gösterilmiştir.

Bu doğrultuda bakıldığında gerek en fazla gerekse en az frekansa sahip sözcük ve kavramlar sonucu bize, AK Partinin bu referandum sürecinde pozitif siyasal iletişim stratejisi izlediğini yukarıda yer alan tweet örneklerinde göstermektedir. Bu tweetlerin en önemli sözcük ve kavramları grafiklerde yeralmıştır.

Bilindiği gibi pozitif siyasal iletişim stratejisinde siyasal aktörün kendini övmesi ve yüceltmesi söz konusudur. Ayrıca bu stratejiyi yürüten siyasal aktör kendisine daha 
fazla olumlu yönde referansta bulunmaktadır. Çalışma bizi 'EVET' cephesinde yer alan (AK Parti ve MHP)nin oldukça yoğun Twitter'ı kullandığı ve pozitif stratejik siyasal iletişim kampanyası yürüttüğü sonucuna götürmüştür. Bu bağlamda bu referendum sürecini çok ciddiye alan AK Parti ve MHP sosyal medyakullanımına önem vermektedirler. Ayrıca bilindiği gibi sosyal medyayı en fazla gençler kullanmaktadır. Bu durumda AK Parti ve MHP'nin sosyal medya kullanıcılarına önem verdiklerinin göstergesidir.

'HAYIR' cephesinde CHP ve HDP yer almıştır. Bilindiği gibi HDP Genel Başkanı Selahattin Demirtaş'ın tutuklu olması sebebiyle HAYIR kampanyasını sadece $\mathrm{CHP}$ yürütmüştür. CHP'nin yürüttügü stratejik siyasal iletişim kampanyasında oldukça az ve sıradan sloganlar kullandığı dikkat çekmiştir. Ayrıca bu CHP kampanyasını ağırlıklı olarak negatif siyasal iletişim stratejisi üzerine kurmuştur. Negatif siyasal iletişim stratejisi olumsuz anlamda eleştirel bir bakış açısı bağlamında yapılmaktadır. Bu süreçte CHP, AK Parti'yi eleştirerek kampanyasına negatif çerçeve çizmiştir. 'HAYIR' cephesinde CHP'nin yalnız kalması HDP'nin sosyal medya Twitter üzerinden kampanyaya katılamaması da bu çalışmada göz önünde bulundurulan bir gerçektir. Bu durum hem HAYIR cephesini hem de CHP'nin kampanyasını zayıf kılmıştır. Ayrıca çalışmanın zayıf kalmasına neden olmuştur.

Sonuç olarak bakıldığında bu çalışma, 16 Nisan 2017 referandumunda, Türkiye Cumhuriyeti tarihinde Cumhurbaşkanı ve siyasi parti genel başkanlarının bir siyasal seçim kampanyası yürütür gibi kampanya yürütmeleri ve bu kampanyalarında sosyal medyanın önemli platformlarından olan Twitter'ı kullanmaları açısından farklılık yaratmıştır. Bu durum ayrıca bu çalışmaya özgünlük katmıştır.

Bu bağlamda Türkiye'de Siyasi parti genel başkanlarının ve Cumhurbaşkanı Recep Tayyip Erdoğan'ın siyasal iletişim faaliyeti olarak sosyal medyayı kullanmaları bu araştırmada incelenmiştir. Çalışma sonucunda AK Parti, MHP ve CHP'nin, 'EVET' ve 'HAYIR' cephelerinde yer alarak oldukça farklı stratejik siyasal iletişim kampanyaları yürüttükleri ortaya konulmuştur. Ortaya çıkan sonuçlar grafiklerle gösterilmiştir.

Araştırma kapsamında incelenen tweetler bizi 'EVET' cephesinin sosyal medyayı yoğun olarak kullandığı sonucuna götürmektedir. EVET cephesinde yeralan AK Parti ve MHP'nin aynı cephede fakat farklı ideolojik boyutlarda siyasal iletişim kampanyası yürüttüklerini gstermiştir. Bu farklı boyutlar MHP'nin Türkçülük AK Partinin islamcllık ideolojisi perspektifinde hareket ederek Türk-İslam sentezi çerçevesinde bu kampanyada ortaklaştıklarını ortaya koymuştur. Ayrıca her iki partide sosyal medyayı çok yoğun kullanmıştır.

'HAYIR' cephesi ise sosyal medyayı hem az kullanmıştır hem de iletilerinde çeşitlilik ve farklılık bulunmamaktadır. Bu durum CHP'nin sosyal medyada siyasal iletişim kampanyasına çok önem vermediğinin göstergesidir. Ayrıca aynı tweetler etrafında dönmeside önem vermemeyi desteklemektedir. Kampanya süresince yalnız kalan CHP, AK Parti ve MHP karşısında zayıf bir stratejik siyasal iletişim kampanyası yürütmüştür. 
Ayrıca araştırmanın zayıf noktası 'HAYIR' cephesinde yeralan 'HDP' nin bu kampanyaya sosyal medya üzerinden katılmamış olmasından kaynaklanmaktadır. HDP Genel Başkanının tutuklu olması bu durumu tetiklemiştir.

Sonuç olarak, 16 Nisan Refrandum sürecine katılan AK parti adına Cumhurbaşkanı ve MHP 'EVET' cephesinde yeralarak başarılı bir sosyal medya kampanyası yürütmüşlerdir.

HAYIR cephesinde yeralan, CHP'nin ise sosyal medyayı daha aktif kullanması önemlidir. Kampanyası başarısız ve sönük geçmiştir. Ayrıca ağırlıklı olarak negatif siyasal iletiler dışında pozitif ve nötr siyasal iletide kullanması kampanyasına çeşitlilik kazandıracaktır. Bunlara ek olarak kampanyasında kullandığı tweetlerin farklı içerikli olması da kampanya stratejisinin başarısını sağlayacaktır.

\section{KAYNAKÇA}

Altınay M., C., Twitter: Gündelik Yaşamın Yeni Rutini Pıt Pıt Net", Sosyal Medya Haber, 05.07.2017, http://www.sosyalmedyahaber.com/akademik-calisma-twitter-gundelikyasamin-yeni rutini-\%E2\%80\%9Cpit-pit-net\%E2\%80\%9D/(05.07.2017).

Kılıçaslan, E. (2016), Siyasal İletişim Açısından Sosyal Medyanın Önemi: 7 Haziran ve 1 Kasım Seçimleri Sürecinde Parti Başkanları ve Cumhur Başkanı'nın Twitter Paylaşımları, (Culture And Communication In Anatolia Past, Present, Future, 15-17 June 2016 yayınlanmış Bildiri).

Kışlalı, Ahmet T., (1987), Siyaset Bilimi, Ankara Üniversitesi Basın Yayın Yüksek Okulu Yayınları, Ankara.

Komito, L., Bates, J. (2009), Virtually local: social media and community among Polish nationals in Dublin. (61 (3), 232-244), Aslib Proceedings: New Information Perspectives.

Mayfield, A. (2008). What is Social Media? iCrossing eBook.Retrieved from: http://www.icrossing.co.uk//fileadmin/uploads/eBooks/What_is_Social_Media_iCrossin g_ebook.pdf.(02.06.2017).

Netdergim, "1 Milyar Kişi Sosyal Medyada" 06.08.2017, http://www.netdergim.com/1-milyarkisi-sosyal-medyada. (06.08.2017).

Özkan N. (2004), Seçim Kazandıran Kampanyalar, İstanbul, Media Cat.

Smith, K. N. (2011). Social Media and Political Campaigns, University of Tennessee Honors Thesis Projects.

http://www.etymonline.com/index.php?search=referendum\&searchmode=none(06.08.2017).

Türk Dil Kurumu İnternet Sitesi TDK, Güncel Türkçe Sözlük, Halk Oylaması,

http://tdk.gov.tr/TR/Soz.Bul.aspx?F6E10F8892433CFFAAF6AA849816B2EF4376734BED947CD \&Kelime=halk\%20oylaması\%4\%b. (06.08.2017).

www.britannica.com/topic/Columbia - Encyclopedia (02.06.2017).

www.medyaakademi.org/2017/06/31/2017-internet-sosyal-medya (31.06.2017).

http://webrazzi.com/genart-ve-nielsenin-turkiyede-twitterkullanici-istatistikleri/(17.7.2017). 